\title{
The drug-naïve OCD patients imaging genetics, cognitive and treatment response study: methods and sample description
}

\author{
Estudo de genética, imagem, coginição e resposta \\ a tratamento em pacientes com TOC virgens de \\ tratamento: métodos e descriç̧ão da amostra
}

\section{Marcelo Queiroz Hoexter, ${ }^{1,2,3}$ Roseli Gedanke Shavitt, ${ }^{1}$ Carina Chaubet D'Alcante, ${ }^{1}$ Janaina Philippi Cecconi, ${ }^{1}$ Juliana Belo Diniz, ${ }^{1}$ Cristina Belotto-Silva, ${ }^{1}$ Ana Gabriela Hounie, ${ }^{1}$ Sonia Borcato, ${ }^{1}$ Ivanil Moraes, ${ }^{1}$ Marines Alves Joaquim, ${ }^{1}$ Carolina Cappi, ${ }^{1}$ Aline Santos Sampaio, ${ }^{1}$ Maria Alice de Mathis, ${ }^{1}$ Marcelo Camargo Batistuzzo, ${ }^{1}$ Antonio Carlos Lopes, ${ }^{1}$ Ana Carolina Ferreira Rosa, ${ }^{1}$ Renan Kawano Muniz, ${ }^{1}$ Andrea Horvath Marques, ${ }^{1}$ Luciana Cristina Santos, ${ }^{1}$ Anita Taub, ${ }^{1}$ Fábio Luís de Souza Duran, ${ }^{1}$ Darin Dean Dougherty, ${ }^{3}$ Geraldo Filho Busatto, ${ }^{1}$ Rodrigo Affonseca Bressan, ${ }^{2,4}$ Euripedes Constantino Miguel $^{1}$}

Abstract

Objective: To describe a protocol that was based on an integrative neurobiological model of scientific investigation to better understand the pathophysiology of obsessive-compulsive disorder and to present the clinical and demographic characteristics of the sample. Method: A standardized research protocol that combines different methods of investigation (genetics, neuropsychology, morphometric magnetic resonance imaging and molecular neuroimaging of the dopamine transporter) obtained before and after treatment of drug-naïve adult obsessive-compulsive disorder patients submitted to a sequentially allocated 12-week clinical trial with a selective serotonin reuptake inhibitor (fluoxetine) and group cognitivebehavioral therapy. Results: Fifty-two treatment-naïve obsessive-compulsive disorder patients entered the clinical trial (27 received fluoxetine and 25 received group cognitive-behavioral therapy). At baseline, 47 blood samples for genetic studies, 50 neuropsychological evaluations, 50 morphometrical magnetic resonance images and 48 TRODAT-1 single-photon emission computed tomography (SPECT) exams were obtained. After 12 weeks, 38 patients completed the protocol (fluoxetine $=20$ and GCBT $=18$ ). Thirty-eight neuropsychological evaluations, 31 morphometrical magnetic resonance images and 34 TRODAT-1 SPECT exams were obtained post-treatment. Forty-one healthy controls matched for age, gender, socioeconomic status, level of education and laterality were submitted to the same research procedures at baseline. Conclusion: The comprehensive treatment response protocol applied in this project allowing integration on genetic, neuropsychological, morphometrical and molecular imaging of the dopamine transporter data in drug-naive patients has the potential to generate important original information on the neurobiology of obsessive-compulsive disorder, and at the same time be clinically meaningful.

Descriptors: Obsessive-compulsive disorder; Genetics; Cognition; Imaging; Treatment outcome

Resumo

Objetivo: Descrever um protocolo integrativo de investigação neurobiológica para melhor compreender as bases patofisiológicas do transtorno obsessivo-compulsivo e apresentar as características clínicas e demográficas da amostra. Método: Protocolo padronizado que combina diferentes modalidades de investigação (genética, neuropsicologia, ressonância magnética cerebral e imagem molecular do transportador de dopamina) obtidas antes e depois do tratamento em pacientes com transtorno obsessivo-compulsivo nunca expostos à medicação submetidos a um ensaio clínico comparando um inibidor seletivo da recaptação de serotonina (fluoxetina) e terapia cognitivo-comportamental em grupo. Resultados: Cinquenta e dois pacientes com transtorno obsessivo-compulsivo entraram no ensaio clínico (27 no grupo fluoxetina e 25 no grupo de terapia). No início, foram realizadas 47 coletas de sangue para genética, 50 avaliações neuropsicológicas, 50 ressonâncias magnéticas cerebrais e 48 exames de tomografia computadorizada por emissão de fóton único (SPECT) com TRODAT-1. Depois de 12 semanas, 38 pacientes terminaram o protocolo (20 no grupo de fluoxetina e 18 no grupo de terapia). Trinta e oito reavaliações neuropsicológicas, 31 ressonâncias magnéticas de crânio e 34 exames de SPECT foram obtidos após o tratamento. Quarenta e um controles pareados foram submetidos ao mesmo protocolo inicial. Conclusão: Os dados genéticos, neuropsicológicos, volumétricos e moleculares do transportador de dopamina aliados à resposta a tratamento podem tanto gerar informações importantes a respeito da neurobiologia do transtorno obsessivo-compulsivo quanto ter uma aplicação clínica.

Descritores: Transtorno obsessivo-compulsivo; Genética; Neuroimagem; Cognição; Resultados de tratamento

${ }^{1}$ Department \& Institute of Psychiatry, Clinical Hospital, Universidade de São Paulo (USP) Medical School, São Paulo (SP), Brazil

${ }^{2}$ Interdisciplinary Laboratory for Clinical Neuroscience (LiNC), Department of Psychiatry, Universidade Federal de São Paulo (UNIFESP), São Paulo (SP), Brazil

${ }^{3}$ Department of Psychiatry, Massachusetts General Hospital, Harvard Medical School, Boston, Massachusetts, USA

${ }^{4}$ Instituto Israelita de Ensino e Pesquisa (IIEP), Hospital Israelita Albert Einstein (HIAE), São Paulo (SP), Brazil

Correspondence

Marcelo Q. Hoexter

R. Ovídio Pires de Campos 785 - 30 and., Ala Norte - sala 9 (PROTOC) 05403-010 São Paulo, SP, Brazil 


\section{Introduction}

Obsessive-compulsive disorder (OCD) has been considered one of the most robust and reliable models supporting pathological brain alterations amongst psychiatric disorders. ${ }^{1}$ However, in contrast to the growing evidence of a biological basis for OCD, there is still limited knowledge regarding its etiology, patterns of cognitive functioning and neurochemical mechanisms. ${ }^{2}$

New genetic and neuroimaging techniques, such as genome wide scans, structural and functional magnetic resonance imaging (MRI), as well as molecular imaging single photon emission computed tomography (SPECT) and positron emission tomography (PET) ${ }^{3}$ are important tools that can help to clarify the pathophysiology of OCD. Such knowledge will allow the identification of individuals at early risk for OCD, the development of novel treatment strategies, as well as the ability to predict response to different interventions. ${ }^{4}$

Twin and family studies have shown the importance of genetic factors for the expression of OCD. Most molecular genetics research has focused on genes encoding neurotransmitters of the serotoninergic, dopaminergic and glutamatergic systems but, except for the glutamate transporter gene, ${ }^{5}$ the results have not been replicated yet. Serotoninergic and dopaminergic molecular imaging studies have also been conducted to evaluate these systems in OCD, with positive ${ }^{6}$ and negative results. ${ }^{7,8}$

The lack of specific trait markers involved in OCD may be related to several potentially confounding factors, including heterogeneous clinical presentation, ${ }^{9}$ high rates of comorbidity, ${ }^{9}$ age of onset ${ }^{10}$ and the effects of exposure to previous treatments (pharmacological and/ or psychotherapeutic) on neural circuits. ${ }^{1,11}$

In addition, a critical issue that limits identification of biological markers for OCD is the small number of controlled longitudinal studies comparing brain alterations following different interventions.

The comparison of different treatments' effects on the brain by means of longitudinal studies would be important for several reasons. First, longitudinal studies allow for measuring brain alterations following a certain intervention. Secondly, since cognitive-behavioral therapy (CBT) and serotonin reuptake inhibitors have proven to be as efficacious as pharmacological treatment in reducing OCD symptoms, ${ }^{12}$ it is crucial to understand their neural mechanisms of action, neurobiological commonalities and differences between them, improving the search for novel treatment strategies. Thirdly, such an approach would provide further information to support clinical decision-making based on neurobiological predictors' patterns, resulting in improved individual patient care.

In this context, the main objective of this manuscript is to describe a standardized research protocol with broad inclusion criteria that combines different methods of investigation (genetics, neuropsychology, structural MRI and molecular neuroimaging of the dopamine transporter) performed before and after treatment of drugnaïve adult OCD outpatients. These outpatients were submitted to a 12-week clinical trial where they were sequentially allocated either to treatment with a selective serotonin reuptake inhibitor (fluoxetine) or group cognitive-behavioral therapy (GCBT). This study investigates the hypothesis that this integrative protocol will provide valid and original information to better understand the pathophysiology of OCD, and, at the same time, be clinically meaningful (Figure 1 , adapted from Linden, 2006). ${ }^{13}$

Moreover, we describe the demographic and clinical characteristics of the sample collected in this study and compare these results with previously published data from 630 patients collected from the Brazilian Research Consortium on Obsessive-Compulsive Spectrum Disorders, ${ }^{14}$ in order to investigate their generalizability.

\section{Method}

All participants were informed about the research procedures and signed an informed consent submitted and approved by the Local Ethics Committee (Universidade de São Paulo, Universidade Federal de São Paulo, and Hospital Israelita Albert Einstein).

This research is part of a larger clinical trial| ${ }^{15,16}$ conducted in our outpatient clinic (The Obsessive-Compulsive Spectrum Disorders Program - PROTOC) specializing in OCD at the Department \& Institute of Psychiatry, Universidade de São Paulo. The primary objective of this trial was to compare, in a setting closer to clinical practice, the clinical effectiveness of SSRI (fluoxetine) and GCBT treatments.

\section{Sample selection}

Patients were referred from primary psychiatric services, from the Brazilian Association of Tourette Syndrome and OCD - ASTOC (www. astoc.org.br), or were recruited through the local media (radio, TV, newspapers, internet).

Healthy controls were recruited among college students, hospital and university staff, or were obtained through word of mouth.

Patients interested in the treatment study went through an initial psychopathological screening by telephone. This first interview was conducted by an experienced psychologist who explained the treatment protocol and obtained an initial gross evaluation of

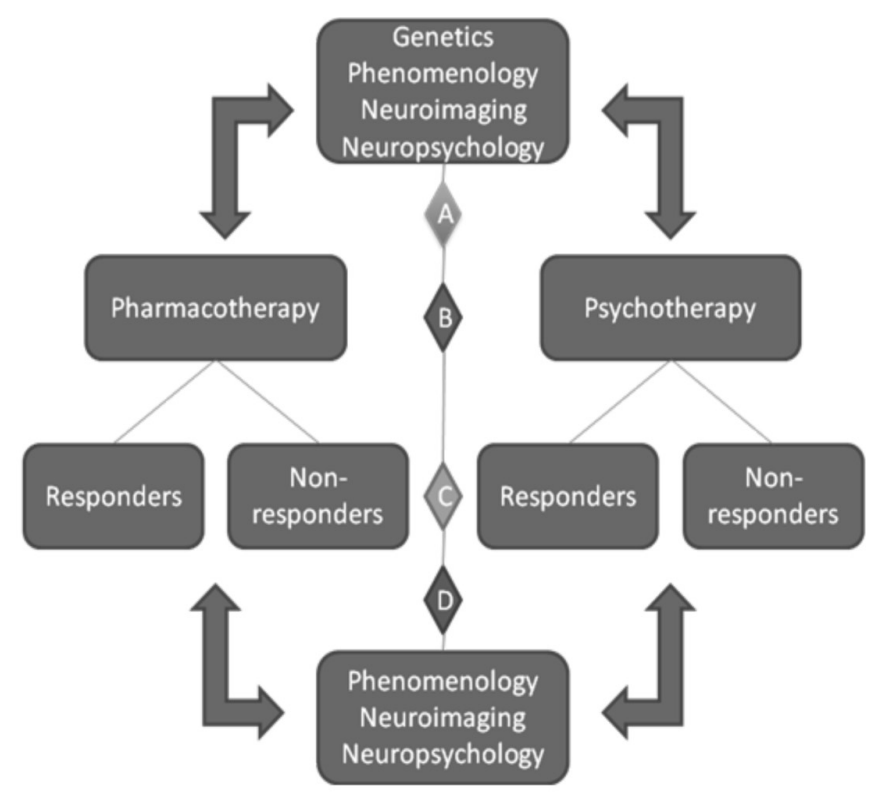

Figure 1 - An integrative model of scientific investigation to better understand the pathophysiology of $O C D$ with potential clinical implications. (A) Neurobiological and phenotypic baseline measures are obtained before treatment initiation; (B) Patients are submitted to standardized different modalities of first line interventions; (C) Based on symptoms improvement following the interventions, patients are classified as responders or non-responders. This outcome information is entered into an analysis of the pretreatment data with the aim of deriving biological or clinical traits that are predictive of treatment response. These pretreatment data may come from imaging, genetics, cognitive patterns, OCD subtypes, comorbidities profile or any other biological or clinical measure assessed at the baseline, (D) Post-treatment neurobiological and phenotypic measures are obtained again. This technique allows identification of brain and clinical changes related to the intervention and their specificity for successful outcome. It also permits the elucidation of commonalities and differences between the interventions.

Adapted from Linden, 2006. 
obsessive-compulsive symptoms and checked for major inclusion/ exclusion criteria. If the subject met the initial basic requirements, a clinical psychiatric appointment was scheduled.

Healthy controls also underwent a psychopathological screening by telephone, performed by the same psychologist. The purpose of this screening was to exclude subjects presenting psychiatric symptoms or contraindications which would prevent them from undergoing the neuroimaging and neuropsychological research procedures. Controls who met the initial requirements were scheduled for a clinical evaluation, made on the basis of structured interviews ("Assessment Package", described below).

After the telephone screening, the selected patients were interviewed by psychiatrists at the OCD outpatient clinic performing the first psychiatric evaluation before enrollment. This interview included: 1) Clinical and psychiatric medical assessment; 2) Structured Clinical Interview screening for DSM-IV Axis I Disorders 3) Physical examination; 4) Electrocardiogram and general blood tests (hemogram, liver and kidney functions, blood glucose levels, electrolytes, thyroid hormones).

Inclusion criteria for this protocol were as follows: 1) age between 18-65 years; 2) to present a primary DSM-IV diagnosis of OCD; 3) Y-BOCS score $\geq 16$ for obsessions and compulsions or $\geq 10$ only for obsessions or compulsions.

Exclusion criteria were: 1) previous exposure to any kind of psychotropic medication (benzodiazepines, antipsychotics, antidepressants, stimulants, mood stabilizers); 2) previous exposure to at least 12 sessions of CBT; 3 ) any condition that could impair the interpretation of results (e.g., a history of skull-brain trauma with post-traumatic amnesia); 4) past or current drug abuse or dependence; 5) past or current history of psychotic symptoms; 6) suicide risk; 7) any significant systemic illness or unstable medical condition; 8) any significant neurological disease.

Inclusion and exclusion criteria for healthy controls were the same, except for the presence of psychiatric disorders.

\section{Assessment instruments}

From eligible patients, an "Assessment Package" was obtained before the treatment allocation process. More details about this Assessment Package and instrument references may be found elsewhere. ${ }^{14}$ This assessment was also obtained from healthy controls after the telephone screening.

Briefly, this package includes: informed consent form, medical history, socio-demographic data, ABIPEME rating scale (a Brazilian scale used to determine socio-economic status), semi-structured interview on family psychiatric history, structured clinical interview for DSM-IV (SCID-I) and additional modules for tic and impulse control disorders, attention deficit hyperactivity disorder (ADHD) and separation anxiety modules of the Kiddie Schedule for Affective Disorders and Schizophrenia (K-SADS), Yale-Brown ObsessiveCompulsive Scale (Y-BOCS), Dimensional Yale-Brown ObsessiveCompulsive Scale (DYBOCS), Yale Global Tic Severity Scale (YGTSS), Beck Depression (BDI) and Anxiety (BAI) Inventories, Universidade de São Paulo Sensory Phenomena Scale (USP-SPS), Brown Assessment of Beliefs Scale (BABS); Social Assessment Scale (SAS); Brazilian version of the Medical Outcomes Study Short Form 36 (SF-36); Clinical Global Impressions Scale (CGI).

\section{Allocation to treatment groups}

A computer program was developed to sequentially allocate patients, ${ }^{17}$ in which prognostic factors such as initial Y-BOCS score, gender, age, and previous treatment history were inserted to calculate the smallest difference of these characteristics between treatment groups. The aim of this method was to minimize possible differences between groups by balancing for possible confounders in a clinical trial that evaluates treatment efficacy. ${ }^{17}$

The allocation process was conducted for each three patients recruited, with two patients allocated to GCBT and one to medication, or vice-versa, according to the necessity of composing treatment groups at each time. Allocation for each group was determined blindly without the knowledge of the professionals responsible for screening, recruiting and following patients. Therefore, there was no possibility of manipulating the insertion of a specific patient into any of the treatments. ${ }^{17}$

\section{Treatments}

Participants were sequentially allocated to one of the two groups of treatment: SSRI (fluoxetine) or GCBT.

1) SSRI treatment ${ }^{15}$

Patients allocated to pharmacological treatment received fluoxetine (up to $80 \mathrm{mg} /$ day) for 12 weeks, starting at $20 \mathrm{mg} /$ day in the first week, with weekly increases of $20 \mathrm{mg} /$ day. Medical appointments were scheduled every four weeks. At the first consultation, patients received a detailed explanation about the delayed onset of therapeutic effects and potential drug side effects. Intolerable side effects were managed by reducing the dosage and, if they persisted at the subsequent consultation, a second SSRI (preferentially sertraline) would be used.

Intermediate scores evaluations (Y-BOCS and CGI) at weeks 4 and 8 were obtained by the psychiatrist responsible for the treatment of each patient (not blinded).

2) GCBT treatment ${ }^{16}$

Patients allocated to GCBT were divided into subgroups of 6-8 patients each and attended a weekly 2 -h session during twelve weeks. The protocol emphasized exercises of exposure and response prevention (EX/RP) and cognitive techniques, such as correction of thoughts and beliefs, and relapse prevention strategies. Patients who missed more than two consecutive sessions were considered drop-outs.

Intermediate scores evaluations (Y-BOCS and CGI) at sessions 4 and 8 were obtained by the psychologist responsible for the treatment of each patient (not blinded).

3) Outcome measures for treatment improvement

After completing 12 weeks of SSRI or GCBT treatment, the following measurements were obtained by a rater blinded to the treatment condition: Y-BOCS, DYBOCS, BDI, BAI, SAS, SF-36 and CGI.

Treatment response was calculated as a continuous variable (percent reduction in baseline Y-BOCS score) and as a categorical variable (or $\geq 35 \%$ reduction in baseline $Y$-BOCS score). Patients presenting $\mathrm{a} \geq 35 \%$ reduction in baseline $\mathrm{Y}$-BOCS score and a CGI score of 1 (much better) or 2 (better) were considered responders.

\section{Database}

All assessments were checked for quality assurance. The whole package was inserted into the database via SPSS Builder (electronic mask).

\section{Genetic, cognitive and imaging assessments}

All drug naïve patients enrolled in the clinical trial described above were invited to participate in the imaging, genetic and cognitive controlled study. For those who were willing to participate, a complete explanation of all the procedures and flowcharts was 
Table 1 - Neuropsychological battery grouped by function

\begin{tabular}{|c|c|}
\hline $\begin{array}{l}\text { Estimated } I Q \text { and } \\
\text { mental functioning }\end{array}$ & $\begin{array}{l}\text { The Wechsler Abbreviated Scale of Intelligence } \\
\left(^{\text {WASI })^{19}}\right.\end{array}$ \\
\hline Attention & $\begin{array}{l}\text { Trail Making Test }{ }^{20} \\
\text { Digit Span - Wechsler Adult Intelligence Scale (WAIS } \\
\text {-III) }\end{array}$ \\
\hline Working Memory & Letter and Number Sequence - WAIS- $1 I^{21}$ \\
\hline Verbal Fluency & Phonemic Fluency (FAS) Test ${ }^{22}$ \\
\hline $\begin{array}{l}\text { Visual memory and } \\
\text { planning capacity }\end{array}$ & $\begin{array}{l}\text { The Rey-Osterrieth Complex Figure } \\
\text { Brief Visual Motor Test (BVMT) }\end{array}$ \\
\hline $\begin{array}{l}\text { Verbal memory and } \\
\text { planning capacity }\end{array}$ & $\begin{array}{l}\text { Logical Memory I and } \|^{23} \\
\text { California Verbal Learning Test (CVLT) }\end{array}$ \\
\hline Motor Skills & $\begin{array}{l}\text { The Finger Tapping } \\
\text { The Grooved Pegboard Test }\end{array}$ \\
\hline Inhibitory Control & $\begin{array}{l}\text { The Go-NoGo Task } \\
\text { Stroop Test }{ }^{28}\end{array}$ \\
\hline Mental Flexibility & $\begin{array}{l}\text { Wisconsin Card Sorting Test (WSCT) })^{29} \\
\text { Object Alternation Task (OAT) })^{30} \\
\text { The Hayling and Brixton Test }{ }^{31}\end{array}$ \\
\hline Decision Making & The lowa Gambling Test (IGT) $)^{32}$ \\
\hline Problem Solving & The Scenarios $^{33}$ \\
\hline Social Skills & The Social Abilities Inventory ${ }^{34}$ \\
\hline
\end{tabular}

given, as summarized in Figure 1. The same sort of explanation was given to the healthy controls recruited for this study. Briefly, the procedures were: blood sample collection for genetics studies, neuropsychological assessment for the cognitive controlled study, structural MRI for the volumetric study and SPECT-TRODAT-1 for the dopamine transporter study. These procedures were performed at baseline for patients and controls. After treatment, patients repeated all these procedures, except for blood sample collection. Whenever possible, a second neuropsychological assessment and MRI exams were obtained from the controls. SPECT-TRODAT-1 evaluation was not obtained again from controls due to ethical issues.

Patients and normal controls were strongly encouraged to participate in the whole protocol, but there were situations where this was not possible such as meeting exclusion criteria for a specific procedure (pacemaker for MRI, for example) or refusing to undergo a specific procedure

1) Blood samples for the genetic studies

Venous blood samples were collected in three tubes of $5 \mathrm{ml}$ with anticoagulant (EDTA). Genomic DNA was extracted from peripheral blood leukocytes of the patients and controls using the salting-out method. ${ }^{18}$ The quality and quantity of the DNA were checked by A260/A280 using a Nanodrop spectrophotometer (Nanodrop Technologies, CA). All DNA samples were stored in a freezer at -80 ${ }^{\circ} \mathrm{C}$ for future genetics studies. More specifically, a variable number of tandem repeats in the 3' untranslated region of the dopamine transporter (SLC6A3) will be investigated for association with in vivo striatal dopamine transporter availability.

2) Neuropychological assessment

A neuropsychological assessment was performed by trained neuropsychologists in a session lasting approximately three hours (Table 1). The application of neuropsychological tests followed a fixed order of presentation, and those that require more concentration were undertaken early in the session for being more susceptible to fatigue. The correction was made by a neuropsychologist "blind" to the type of treatment received. Patients and controls were excluded if they presented learning disabilities such as dyslexia, dyscalculia or dysgraphia.

3) Structural MRI for the morphometric study

Images were acquired using a 1.5 T GE Signa scanner (General
Electric, Milwaukee WI, USA). Contiguous $1.6 \mathrm{~mm}$ axial images across the entire brain were acquired, using a T1-3D SPGR sequence providing 248 contiguous slices, voxel size $=0.94 \mathrm{~mm}$ $\times 0.94 \mathrm{~mm} \times 0.80 \mathrm{~mm}, \mathrm{TE}=4.20 \mathrm{~ms}, \mathrm{TR}=10.5 \mathrm{~ms}$, flip angle $=15$, acquisition matrix $=256 \times 192$.

Patients and controls were not eligible for MRI study if they presented a history of significant head trauma followed by loss of consciousness or had known structural brain abnormalities. Claustrophobia, presence of pacemakers, aneurysm clips, artificial heart valves, and ear implants, metal fragments or foreign objects in the eyes, skin or body were also impeditive.

4) SPECT of the dopamine transporter for the molecular imaging study

SPECT scans were performed with [Tc99m]-TRODAT-1, a radiotracer with high selectivity and specificity for the dopamine transporter. TRODAT-1 kits were produced by the Institute of Nuclear Energy Research (INER-Taiwan R.O.C.) and labeled according to Choi et al. ${ }^{35}$ Images were acquired four hours after the injection of $740 \mathrm{MBq}(20 \mathrm{mCi})$ of [Tc99m]-TRODAT-1 using a Dual-head gamma camera "Hawk Eye" (General Electric Medical System, USA), equipped with high-resolution fan beam collimators. For each scan a total of 128 projections (30s per frame) were collected in a step-and-shoot mode on circular $360^{\circ}$ orbit in a $128 \times 128$ matrix with the mean radius of rotation of $15.5 \mathrm{~cm} .{ }^{36}$

The image data were reconstructed by standard filtered back projection using a Butterworth filter (cut-off frequency 0.45) with attenuations by Chang's method.

Patients and controls were not eligible for SPECT if they were allergic to chemicals in the radioactive tracer, or were pregnant or breast-feeding.

\section{Statistical analyses}

To describe the demographic and clinical characteristics of the sample, the Mann-Whitney test was used to compare numerical variables, whereas the Chi-square test was used for categorical variables. The Chi-square test with Yates' continuity correction was used when fewer than 5 patients were analyzed for a given variable. All statistical tests were interpreted with $5 \%$ level of significance.

\section{Results}

\section{Sample enrollment}

Figure 2 depicts the enrollment, allocation, follow-up and data acquisition from patients and controls.

Six hundred and twenty-three preliminary telephone screenings of patients were performed from the beginning of 2006 to the end of 2008. Three hundred and sixty nine potential OCD subjects were then evaluated by the psychiatric team. Of these, $78(21.1 \%)$ were drug naïve, but only 52 participated in this protocol and were sequentially allocated as follows: 27 to SSRI (fluoxetine) (51.9\%) and 25 to GCBT (48.1\%).

Fifty four potential healthy controls were screened by telephone from the beginning of 2006 to the end of 2008 and 44 (81.5\%) were eligible for the study, but only 41 were enrolled in the protocol because 3 screened controls declined to participate prior to the procedures. Reasons for ineligibility were: 1 potential control had past head trauma followed by a loss of consciousness, 3 controls had psychiatric disorders screened by the SCID, 1 control had a significant family history of depression, 1 control had past use of amphetamines to lose weight, 1 had taken bupropion, 2 did not have the appropriate level of education required and 1 declined after reading the protocol.

After 12 weeks of treatment, 38 of the 52 drug naïve patients (73.1\%) finished the protocol. Of those, 20 belonged to the 


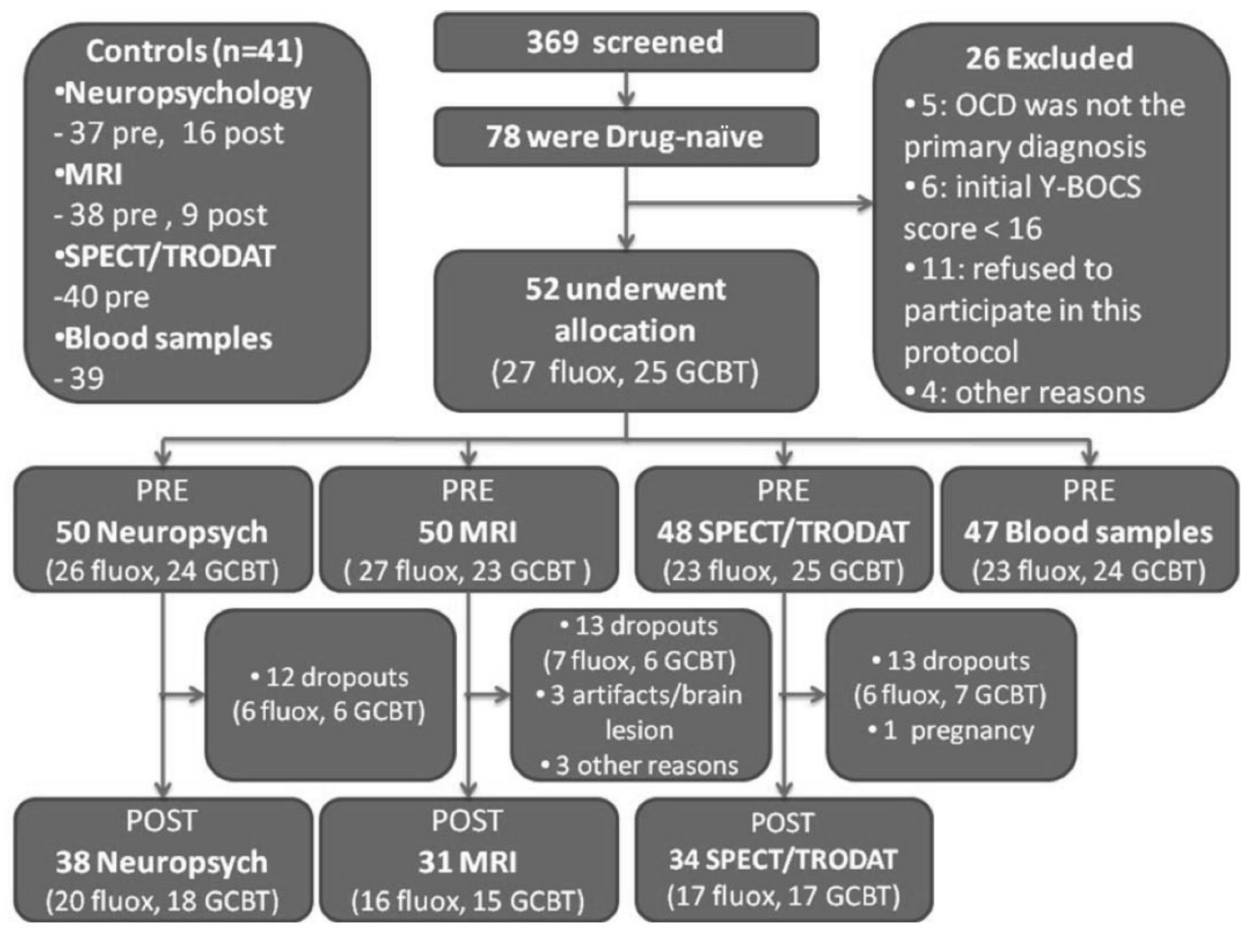

Figure 2 - Enrollment, allocation, and follow-up of patients and controls in the study

fluoxetine group and 18 to the GCBT. Dropout rates were $25.9 \%$ in the SSRI group $(n=7)$ and $28 \%$ in the GCBT $(n=7)$ $(p=0.87)$. The main reasons related to discontinuation/not initiation of treatment in the fluoxetine group were: 2 patients failed to initiate treatment due to allocation dissatisfaction, 3 patients reported lack of time to comply with scheduled consultations, 1 patient had side effects and stopped taking the medication of their own accord, and 1 patient missed a consultation and had to stop taking the medication. Among patients in GCBT, the reasons for treatment discontinuation were: 2 patients did not come for the initial consultation, 1 patient stopped the treatment due to allocation dissatisfaction, 1 patient missed the last therapy session and did not complete the outcome instruments, 2 patients stopped the treatment due to improvement of symptoms after some sessions and 1 patient had to start antidepressants due to depressive symptoms.

Sixteen neuropsychological assessments were also performed on controls after 12 weeks and $9 \mathrm{MRI}$ exams were acquired after a period varying from 10 to 18 months.

\section{Sample characteristics}

Baseline demographic and clinical characteristics of patients and controls enrolled in the study are shown in Table 2 . The groups were balanced for age, gender, level of education, socioeconomic status and handedness. The mean age of obsessive-compulsive symptoms onset was 12.9 (S.E. = 1.04) years and 17.8 (S.E. $=1.36)$ years had passed from the first symptom onset. Patients had a mean Y-BOCS score of 25.5 (S.E. = 0.69) points. As predicted, there were statistically significant differences between the groups on measures of obsessive-compulsive symptom dimensions, depression and anxiety severities. Among patients, the commonest symptom dimension was symmetry/ordering, following by aggression, contamination/cleaning, hoarding and sexual/religious. Patients were also more impaired than controls in terms of their professional activity $(p=0.05)$.

As also expected, given the relatively broad inclusion criteria of the study, the patients' comorbidity profile was also diverse (Table 3). Generalized anxiety disorder, major depression, social phobia and simple phobia were the most prevalent comorbidities, found both for current and lifetime status investigation. Lifetime presence of obsessive compulsive spectrum disorders, such as body dysmorphic disorder, hypochondria, Tourette syndrome, trichotillomania and somatization disorder represented $15 \%$ or less of the sample.

\section{Drug-Naïve OCD patients versus OCD Consortium patients}

Table 4 shows the main clinical and sociodemographic characteristics of the drug-naïve OCD patients in comparison to the Brazilian OCD Consortium patients. No statistically significant differences were found in the sociodemographic characteristics or OCS content, except for age, illness duration, "other" symptom dimensions (miscellaneous dimension), depression (BDI) and anxiety (BAI) scores and, obviously, for previous psychiatric treatment. Drug-naïve patients were younger, had shorter illness duration, had higher depression and anxiety scores, more miscellaneous symptoms and had never experienced psychiatric treatment. Eighteen (34.6\%) of the drug-naïve patients had been submitted to psychotherapy, but just two patients had received CBT in the past. The lifetime Axis I psychiatric comorbidities comparison did not differ statistically between drug-naïve and consortium OCD patients.

\section{Discussion}

This paper describes a standardized research protocol which aims to generate information in order to establish an integrative model for the scientific investigation of the pathophysiology of OCD 
Table 2 - Demographic and clinical data of the sample

\begin{tabular}{|c|c|c|c|}
\hline \multirow[t]{2}{*}{ Variable } & $\begin{array}{l}\text { OCD drug-naïve } \\
\text { patients } \\
(\mathrm{n}=52)\end{array}$ & $\begin{array}{l}\text { Healthy } \\
\text { controls } \\
(n=41)\end{array}$ & Analysis \\
\hline & \multicolumn{2}{|c|}{ Mean (SE) } & $p$-value ${ }^{\dagger}$ \\
\hline Age, $y$ & $30.8(1.31)$ & $27.7(1.21)$ & 0.11 \\
\hline Age of onset, $y$ & $12.9(1.04)^{*}$ & - & - \\
\hline Illness duration, y & $17.8(1.36)^{\star \star}$ & - & - \\
\hline Age of diagnosis, $y$ & $29.9(1.26)^{* * *}$ & - & - \\
\hline \multicolumn{4}{|l|}{ Y-BOCS score, } \\
\hline Obsessions & $12.5(0.40)$ & - & - \\
\hline Compulsions & $13(0.38)$ & - & - \\
\hline Total & $25.5(0.69)$ & - & - \\
\hline BDI & $18.1(1.27)$ & $2.5(0.39)$ & $<0.001$ \\
\hline \multirow[t]{2}{*}{ BAI } & $18.3(1.63)$ & $1.8(0.24)$ & $<0.001$ \\
\hline & \multicolumn{2}{|c|}{ No. $(\%)$} & p-value ${ }^{t \dagger}$ \\
\hline Gender, female & $34(65.4)$ & $24(58.5)$ & 0.5 \\
\hline Caucasian & $44(84.6)$ & $33(80.5)$ & 0.60 \\
\hline \multicolumn{4}{|l|}{$\begin{array}{l}\text { Presence of symptoms } \\
\text { dimension (DY-BOCS) }\end{array}$} \\
\hline Aggression & $40(76.9)$ & $1(2.4)$ & $<0.001$ \\
\hline Sexual/religious & $25(48.1)$ & $0(0)$ & $<0.001$ \\
\hline Symmetry/ordering & $47(90.4)$ & $10(24.4)$ & $<0.001$ \\
\hline Contamination/cleaning & $35(67.3)$ & $2(4.9)$ & $<0.001$ \\
\hline Hoarding & $27(51.9)$ & $4(9.7)$ & $<0.001$ \\
\hline Miscellaneous & $51(98.1)$ & $5(12.2)$ & $<0.001$ \\
\hline Level of education, & & & 0.24 \\
\hline $\begin{array}{l}\text { Complete tertiary } \\
\text { education }\end{array}$ & $15(28.8)$ & $14(34.1)$ & \\
\hline $\begin{array}{l}\text { Incomplete tertiary } \\
\text { education }\end{array}$ & $8(15.4)$ & $12(29.3)$ & \\
\hline $\begin{array}{l}\text { Complete secondary } \\
\text { education }\end{array}$ & $26(50)$ & $14(34.1)$ & \\
\hline $\begin{array}{l}\text { incomplete secondary } \\
\text { education }\end{array}$ & $3(5.8)$ & $1(2.4)$ & \\
\hline \multicolumn{4}{|l|}{ Socioeconomic status } \\
\hline Classes a/b (higher) & $32(61.5)$ & $29(70.7)$ & 0.35 \\
\hline Classes c/d/e (lower) & $20(38.5)$ & $12(29.3)$ & \\
\hline \multicolumn{4}{|l|}{ Employment status } \\
\hline Current unemployed & $9(17.3)$ & $1(2.4)$ & 0.05 \\
\hline Others ${ }^{t+t}$ & $43(82.7)$ & $40(97.6)$ & \\
\hline Handededness, right & $49(94.2)$ & $40(97.6)$ & 0.79 \\
\hline
\end{tabular}

N: number of subjects; Y-BOCS: Yale-Brown Obsessive-Compulsive Scale; DYBOCS: Dimensional Yale-Brown Obsessive-Compulsive Scale; SE: standard error; BDI: Beck Depression Inventory; BAI: Beck Anxiety Inventory; OCS: Obsessive-Compulsive Symptoms; ${ }^{\dagger}$ Mann-Whitney $U$ tests; ${ }^{t+} X^{2}$ Chi-Square test; ${ }^{t t t}$ Others: includes current employment, retirement, part time studies and unwaged domestic work. Full time students were considered currently employed; * 1 data missing; ** 2 data missing; ${ }^{* * *} 3$ data missing

and secondly to be clinically meaningful (Figure 1 ). In addition, it depicted the demographic and clinical characteristics of the present sample comparing these results with previously collected data from 630 patients from the Brazilian Research Consortium on ObsessiveCompulsive Spectrum Disorders. ${ }^{14}$

The present protocol involved blood sample collection for genetic studies and assessment of several clinical and neurobiological (neuropsychology, structural MRI, SPECT of the dopamine transporter) measures before and after two standardized treatments (pharmacotherapy and psychotherapy) in a relatively large and rare sample of adult OCD patients who had never been exposed to any psychotropic medication or CBT (Figure 2).
In order to achieve reliable neurobiological comparisons, drug-naïve patients and healthy controls were well characterized phenotypically, and were matched for the mainly sociodemographic characteristics such as age, gender, level of education, socioeconomic status and handedness (Table 2). Additionally, as a result of the allocation process, the number of patients allocated to SSRI $(51.9 \%)$ or GCBT $(48.1 \%)$ was similar. Following the interventions, there were no differences in the dropout rates for each intervention (28\% for GCBT versus $25.9 \%$ for SSRI). These rates were similar to those found in a recent study from our group evaluating abandonment rates among OCD patients (drug-naïve and non-drug-naïve patients) enrolled in the larger clinical trial during two years of follow up (Diniz et al., unpublished observations).

An interesting point to be addressed is whether the OCD drug naïve patients would have different clinical and socio-demographic characteristics from previously treated patients that sought treatment at our service. To address this question, we compared the clinical and demographic characteristics of the present sample with data from 630 OCD patients studied by the Brazilian Research Consortium on Obsessive-Compulsive Spectrum Disorders ${ }^{14}$ (Table 4).

As expected, the preliminary comparisons showed that drug-naïve patients were younger and had shorter illness duration. Additionally, they presented more symptoms from the miscellaneous dimension. Interestingly, they presented the same age at onset and the same time gap before starting treatment. This similarity in profile may have occurred as a result of our close relationship with the Brazilian Association of Patients with OCD and TS (ASTOC); due to our robust recruitment process, or because it is not common for primary and

Table 3 - Current and lifetime drug-naïve axis I comorbidities

\begin{tabular}{|c|c|c|}
\hline Comorbid disorders, No. (\%) & Current & Lifetime \\
\hline \multicolumn{3}{|l|}{ Affective disorders } \\
\hline Major depression & $18(34.6)$ & $31(59.6)$ \\
\hline Dysthimia & $9(17.3)$ & $9(17.3)$ \\
\hline Bipolar I & $1(1.9)$ & $1(1.9)$ \\
\hline Bipolar II & $2(3.8)$ & $2(3.8)$ \\
\hline \multicolumn{3}{|l|}{ Anxiety disorders } \\
\hline Generalized anxiety disorder & $20(38.5)$ & $21(40.4)$ \\
\hline Social phobia & $20(38.5)$ & $24(46.2)$ \\
\hline Simple phobia & $15(28.8)$ & $18(34.6)$ \\
\hline Post traumatic stress disorder & $3(5.8)$ & $11(21.2)$ \\
\hline Panic disorder/agoraphobia & $3(5.8)$ & $3(5.8)$ \\
\hline Agoraphobia & $3(5.8)$ & $4(7.7)$ \\
\hline Panic disorder & $0(0)$ & $4(7.7)$ \\
\hline \multicolumn{3}{|l|}{ Eating disorders } \\
\hline Binge-eating disorder & $1(1.9)$ & $3(5.8)$ \\
\hline Anorexia nervosa & $0(0)$ & $3(5.8)$ \\
\hline Bulimia nervosa & $1(1.9)$ & $2(3.8)$ \\
\hline \multicolumn{3}{|l|}{ Somatoform disorders } \\
\hline Somatization & $2(3.8)$ & $2(3.8)$ \\
\hline Hypochondriasis & $1(1.9)$ & $1(1.9)$ \\
\hline Body dysmorphic disorder & $4(7.7)$ & $8(15.4)$ \\
\hline \multicolumn{3}{|l|}{ Impulse-control disorders } \\
\hline Kleptomania & $1(1.9)$ & $1(1.9)$ \\
\hline Pathological gambling & $0(0)$ & $1(1.9)$ \\
\hline Compulsive buying & $3(5.8)$ & $6(11.5)$ \\
\hline Trichotillomania & $3(5.8)$ & $3(5.8)$ \\
\hline Skin picking & $8(15.4)$ & $11(21.2)$ \\
\hline Intermittent explosive disorder & $8(15.4)$ & $10(19.2)$ \\
\hline Compulsive sexual behavior & $2(3.8)$ & $3(5.8)$ \\
\hline \multicolumn{3}{|l|}{ Other disorders } \\
\hline Tourette disorder & $2(4)$ & $3(6)$ \\
\hline $\begin{array}{l}\text { Attention-deficit/hyperactivity } \\
\text { disorder }\end{array}$ & $3(5.8)$ & $3(5.8)$ \\
\hline
\end{tabular}


Table 4 - Drug-naïve and consortium OCD demographic and clinical data

\begin{tabular}{|c|c|c|c|}
\hline \multirow[t]{2}{*}{ Variable } & $\begin{array}{l}\text { OCD Drug- } \\
\text { naïve patients } \\
(\mathrm{n}=52)\end{array}$ & $\begin{array}{l}\text { Consortium } \\
\text { OCD patients } \\
(n=630)\end{array}$ & \multirow{2}{*}{$\begin{array}{l}\text { Analysis } \\
\text { p-value }^{\ddagger \ddagger}\end{array}$} \\
\hline & \multicolumn{2}{|c|}{ Mean (SE) } & \\
\hline Age, $y$ & $30.8(1.31)$ & $34.7(0.51)$ & 0.04 \\
\hline Age of onset, $y$ & $12.9(1.04)^{*}$ & $12.9(0.31)^{* * *}$ & $0.98^{\ddagger \ddagger}$ \\
\hline $\begin{array}{l}\text { Illness duration, mean } \\
(\mathrm{SE}), y\end{array}$ & $17.8(1.36)^{* *}$ & $21.9(0.54)^{\star \star *}$ & $0.04^{\ddagger \ddagger}$ \\
\hline $\begin{array}{l}\text { Gap before starting } \\
\text { treatment, } y\end{array}$ & $16.8(1.39)$ & $16.5(0.53)^{\dagger}$ & $0.40^{\ddagger \ddagger}$ \\
\hline Age of first treatment, $y$ & $29.3(1.26)$ & $29.2(0.51)^{\dagger t}$ & $0.98^{\ddagger \ddagger}$ \\
\hline \multicolumn{4}{|l|}{$\begin{array}{l}\text { Y-BOCS score, mean } \\
\text { (SE) }\end{array}$} \\
\hline Obsessions & $12.5(0.40)$ & $12.3(0.17)$ & $0.78^{\ddagger \ddagger}$ \\
\hline Compulsions & $13(0.38)$ & $12.6(0.18)$ & $0.98^{\ddagger \ddagger}$ \\
\hline Total & $25.5(0.69)$ & $24.9(0.32)^{t+t}$ & $0.98^{\ddagger \ddagger}$ \\
\hline BDI & $18.1(1.27)$ & $15.5(0.45)^{\ddagger}$ & $0.04^{\ddagger \ddagger}$ \\
\hline \multirow[t]{2}{*}{ BAI } & $18.3(1.63)$ & $15.1(0.46)^{\ddagger}$ & $0.04^{\ddagger \ddagger}$ \\
\hline & \multicolumn{2}{|c|}{ No. (\%) } & $p$-value \\
\hline Gender, female & $34(65.4)$ & $355(56.3)$ & 0.21 \\
\hline Caucasian & $44(84.6)$ & $533(84.6)$ & 0.99 \\
\hline \multicolumn{4}{|l|}{$\begin{array}{l}\text { Presence of symptoms } \\
\text { dimension (DY-BOCS) }\end{array}$} \\
\hline Aggression & $40(76.9)$ & $413(65.6)$ & 0.09 \\
\hline Sexual/religious & $25(48.1)$ & $318(50.5)$ & 0.74 \\
\hline Symmetry/ordering & $47(90.4)$ & $552(87.6)$ & 0.56 \\
\hline Contamination/cleaning & $35(67.3)$ & $456(72.4)$ & 0.43 \\
\hline Hoarding & $27(51.9)$ & $315(50)$ & 0.79 \\
\hline Miscellaneous & $51(98.1)$ & $548(87)$ & 0.03 \\
\hline \multicolumn{4}{|l|}{ Socioeconomic status } \\
\hline Classes a/b (higher) & $32(61.5)$ & $371(58.9)$ & 0.7 \\
\hline Classes c/d/e (lower) & $20(38.5)$ & $259(41.1)$ & \\
\hline Psychiatric Treatment & $0(0)$ & $477(75.7)$ & $<0.001$ \\
\hline Any psychotherapy & $18(34.6)$ & $411(65.2)$ & $<0.001$ \\
\hline \multicolumn{4}{|l|}{ Employment status } \\
\hline Current unemployed & $9(17.3)$ & $91(14.4)$ & 0.57 \\
\hline Others $^{\perp}$ & $43(82.7)$ & $539(85.6)$ & \\
\hline \multicolumn{4}{|l|}{ Course of symptoms } \\
\hline Chronic/continuous & $5(9.6)$ & $39(6.2)$ & 0.25 \\
\hline Waxing/waning & $10(19.2)$ & $200(31.7)$ & \\
\hline Episodic & $11(21.2)$ & $87(13.8)$ & \\
\hline Worsening & $19(36.5)$ & $210(33.3)$ & \\
\hline Other & $7(13.5)$ & $94(14.9)$ & \\
\hline
\end{tabular}

N: number of subjects; Y-BOCS: Yale-Brown Obsessive-Compulsive Scale; DYBOCS: Dimensional Yale-Brown Obsessive-Compulsive Scale; SE: standard error; BDI: Beck Depression Inventory; BAI: Beck Anxiety Inventory; OCS: Obsessive-Compulsive Symptoms; ${ }^{\sharp \pm}$ Mann-Whitney $U$ tests; ${ }^{\sharp \pm} X^{2}$ Chi-Square test; ${ }^{\perp}$ others: includes current employment, retirement, part time studies and unwaged domestic work. Full time students were considered currently employed; * 1 data missing; ${ }^{* *} 2$ data missing; *** 39 data missing; ${ }^{+} 64$ data missing; ${ }^{\text {t+ }} 35$ data missing; ${ }^{+t+} 12$ data missing; ${ }^{\ddagger} 17$ data missing.

secondary health services in our city to offer specialized treatment for OCD. The long delay before seeking treatment observed in drug naïve and consortium patients reinforces the concept that OCD is a hidden disorder, in which patients are secretive and embarrassed about their symptoms. ${ }^{37}$ Patients in the drug naïve group had slightly higher depression and anxiety scores. The slightly better scores in depression and anxiety scales of the consortium patients could reflect the fact that the majority of these patients (75\%) were already in treatment when the assessments were made. ${ }^{14}$ Of note, the severity of obsessive-compulsive symptoms measured by the
Y-BOCS was similar for both groups, as well as the comorbidity and symptom dimension profiles.

Though the comorbid axis I conditions observed in this study are similar to the profile reported in most OCD clinical investigations, ${ }^{14}$ in which comorbid major depressive disorder and anxiety disorders in general are highly frequent, and despite the fact that the core features of OCD are relatively alike worldwide, ${ }^{38}$ our results cannot be directly generalized to the overall OCD population given our specific effort to investigate drug naïve patients.

This study has some limitations. Firstly, not all patients and controls were submitted to all the investigation procedures. In addition, given the broad inclusion criteria adopted to build a setting closer to clinical practice, many comorbidities were not excluded. Although broader inclusion criteria lead to study samples more likely to represent a real population, ${ }^{39}$ this approach has the disadvantage of including too many comorbidities which may confuse the interpretation of neurobiological findings.

Finally, genetic, cognitive and imaging studies are extremely relevant to understanding the neurobiology of mental disorders. Future studies with larger sample sizes are necessary to increase the statistical power of the neurobiological measures. In this sense, the establishment of collaborative multicenter neuroimaging and neuropsychological protocols is essential, with the ultimate goal of developing more individualized treatments.

In conclusion, this study has many important methodological strengths, which will give credibility for its future findings in genetic, neuropsychological and imaging studies. First, a large sample of OCD drug-naïve patients was included. Second, this is a longitudinal study in which the clinical sample was allocated to two different modalities of intervention proven to be effective in reducing obsessivecompulsive symptoms. Third, patients and healthy controls were matched and well characterized phenotypically. Fourth, given the complexity of mental disorders, an approach integrating different modalities of investigation (genetic, phenomenology, neuroimaging and neuropsychology) with a treatment intervention may represent a more powerful tool for understanding the neurobiology of OCD and the same time its clinical relevance. Lastly, the comparison of this sample with a national sample suggests that the clinical features of the present drug-naïve OCD sample are representative of the general OCD population.

\section{Acknowledgments}

This study received financial support in the form of grants provided by the following Brazilian governmental agencies: the Conselho Nacional de Desenvolvimento Científico e Tecnológico (CNPq, National Council for Scientific and Technological Development, Grant number: 521369/96-7, 475919/2006-8 and 481791/2004-3); and the Fundação de Amparo à Pesquisa do Estado de São Paulo (FAPESP, Foundation for the Support of Research in the State of São Paulo, Grant number: 2005/55628-08, 06/61459-7 and 06/50273-0). It also received support from the Instituto Israelita de Ensino e Pesquisa do Hospital Israelita Albert Einstein (IIEPHIAE) (Process: 150-06). Dr. Hoexter is supported by a PhD scholarship from FAPESP (Process: 2005/04206-6) and by a doctorate "sandwich" from the Coordenação de Aperfeiçoamento de Pessoal de Nivel Superior (CAPES, Agency for Support and Evaluation of Graduate Education) (Process: BEX 4375/08-4).

We gratefully acknowledge all patients and controls who participated in this study. 
Disclosures

\begin{tabular}{|c|c|c|c|c|c|c|c|}
\hline $\begin{array}{l}\text { Writing group } \\
\text { member }\end{array}$ & Employment & $\begin{array}{l}\text { Research } \\
\text { grant }^{1}\end{array}$ & $\begin{array}{l}\text { Other research grant or } \\
\text { medical continuous } \\
\text { education }\end{array}$ & $\begin{array}{l}\text { Speaker's } \\
\text { honoraria }\end{array}$ & $\begin{array}{c}\text { Ownership } \\
\text { interest }\end{array}$ & $\begin{array}{l}\text { Consultant/ } \\
\text { advisory board }\end{array}$ & Other $^{3}$ \\
\hline $\begin{array}{l}\text { Marcelo Queiroz } \\
\text { Hoexter }\end{array}$ & $\begin{array}{l}\text { IPq-FMUSP } \\
\text { UNIFESP }\end{array}$ & $\begin{array}{l}\text { FAPESP } \\
\text { CAPES }\end{array}$ & - & - & - & - & - \\
\hline $\begin{array}{l}\text { Roseli Gedanke } \\
\text { Shavitt }\end{array}$ & IPq FMUSP & FAPESP & - & - & - & - & - \\
\hline $\begin{array}{l}\text { Carina Chaubet } \\
\text { D'Alcante }\end{array}$ & IPq FMUSP & FAPESP & - & - & - & - & - \\
\hline $\begin{array}{l}\text { Janaina Philippi } \\
\text { Cecconi }\end{array}$ & IPq FMUSP & - & - & - & - & - & - \\
\hline $\begin{array}{l}\text { Juliana Belo } \\
\text { Diniz }\end{array}$ & IPq FMUSP & FAPESP & - & - & - & - & - \\
\hline $\begin{array}{l}\text { Cristina Belotto- } \\
\text { Silva }\end{array}$ & IPq FMUSP & FAPESP & - & - & - & - & - \\
\hline $\begin{array}{l}\text { Ana Gabriela } \\
\text { Hounie }\end{array}$ & IPq FMUSP & CAPES & - & - & - & - & - \\
\hline Sonia Borcato & IPq FMUSP & - & - & - & - & - & - \\
\hline Ivanil Moraes & IPq FMUSP & - & - & - & - & - & - \\
\hline $\begin{array}{l}\text { Marines Alves } \\
\text { Joaquim }\end{array}$ & IPq FMUSP & - & - & - & - & - & - \\
\hline Carolina Cappi & IPq FMUSP & - & - & - & - & - & - \\
\hline $\begin{array}{l}\text { Aline Santos } \\
\text { Sampaio }\end{array}$ & IPq FMUSP & CAPES & - & - & - & Johnson\&Johnson's & - \\
\hline $\begin{array}{l}\text { Maria Alice de } \\
\text { Mathis }\end{array}$ & IPq FMUSP & FAPESP & - & - & - & - & - \\
\hline $\begin{array}{l}\text { Marcelo } \\
\text { Camargo } \\
\text { Batistuzzo }\end{array}$ & IPq FMUSP & - & - & - & - & - & - \\
\hline $\begin{array}{l}\text { Antonio Carlos } \\
\text { Lopes }\end{array}$ & IPq FMUSP & FAPESP & - & - & - & - & - \\
\hline $\begin{array}{l}\text { Ana Carolina } \\
\text { Ferreira Rosa }\end{array}$ & IPq FMUSP & - & - & - & - & - & - \\
\hline $\begin{array}{l}\text { Renan Kawano } \\
\text { Muniz }\end{array}$ & IPq FMUSP & - & - & - & - & - & - \\
\hline $\begin{array}{l}\text { Andrea Horvath } \\
\text { Marques }\end{array}$ & IPq FMUSP & NARSAD & - & - & - & - & - \\
\hline $\begin{array}{l}\text { Luciana Cristina } \\
\text { Santos }\end{array}$ & IPq FMUSP & - & - & - & - & - & - \\
\hline Anita Taub & IPq FMUSP & - & - & - & - & - & - \\
\hline $\begin{array}{l}\text { Fábio Luís de } \\
\text { Souza Duran }\end{array}$ & IPq FMUSP & - & - & - & - & - & \\
\hline $\begin{array}{l}\text { Darin Dean } \\
\text { Dougherty }\end{array}$ & $\begin{array}{l}\mathrm{MGH} \\
\mathrm{HMS}\end{array}$ & $\begin{array}{c}\text { Cyberonics }^{\star *} \\
\text { Medtronic**} \\
\text { Eli-Lilly** } \\
\text { Northstar } \\
\text { Neuroscience }\end{array}$ & - & $\begin{array}{c}\text { Reed Elsevier } \\
\text { Medtronic } \\
\text { Eli-Lilly } \\
\text { Jazz } \\
\text { Pharmaceuticals } \\
\text { Wyeth } \\
\text { Bristol Myers } \\
\text { Squibb } \\
\text { Brand Ideas } \\
\text { McNeil } \\
\end{array}$ & - & $\begin{array}{c}\text { Reed Elsevier } \\
\text { Medtronic } \\
\text { Eli-Lilly } \\
\text { Jazz } \\
\text { Pharmaceuticals } \\
\text { Wyeth } \\
\text { Bristol Myers } \\
\text { Squibb } \\
\text { Brand Ideas } \\
\text { McNeil } \\
\end{array}$ & - \\
\hline $\begin{array}{l}\text { Geraldo Filho } \\
\text { Busatto }\end{array}$ & IPq FMUSP & - & - & - & - & - & - \\
\hline $\begin{array}{l}\text { Rodrigo } \\
\text { Affonseca } \\
\text { Bressan }\end{array}$ & $\begin{array}{l}\text { UNIFESP } \\
\text { Instituto Albert } \\
\text { Einstein de } \\
\text { Ensino e } \\
\text { Pesquisa }\end{array}$ & 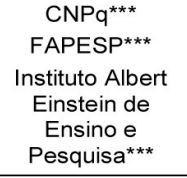 & $\begin{array}{c}\text { Novartis***} \\
\text { Eli-Lilly***} \\
\text { Janssen-Cilag*** } \\
\text { AstraZeneca*** }\end{array}$ & $\begin{array}{c}\text { Novartis* } \\
\text { Eli-Lilly* } \\
\text { Janssen-Cilag* } \\
\text { AstraZeneca* }\end{array}$ & - & $\begin{array}{l}\text { Astra-Zeneca* } \\
\text { Janssen-Cilag* }\end{array}$ & $\begin{array}{c}\text { AstraZeneca* } \\
\text { Eli-Lilly* } \\
\text { Janssen- } \\
\text { Cilag* }\end{array}$ \\
\hline $\begin{array}{l}\text { Euripedes } \\
\text { Constantino } \\
\text { Miguel }\end{array}$ & IPq FMUSP & $\begin{array}{l}\text { CNPQ }^{* * *} \\
\text { FAPESP }^{* * *} \\
\text { CAPES }^{* *} \\
\text { USP } \\
\text { NARSAD }\end{array}$ & - & Solvay* & - & - & - \\
\hline
\end{tabular}

* Modest

** Significant

*** Significant. Amounts given to the author's institution or to a colleague for research in which the author has participation, not directly to the author

Note: Ipq-FMUSP = Instituto de Psiquiatria, Faculdade de Medicina, Universidade de São Paulo; UNIFESP = Universidade Federal de São Paulo; MGH =

Massachusetts General Hospital; HMS = Harvard Medical School; FAPESP = Fundação de Amparo a Pesquisa de São Paulo; CAPES = Coordenação de

Aperfeiçoamento de Pessoal de Nivel Superior; NARSAD = National Alliance for Research on Schizophrenia and Depression; CNPq = Conselho Nacional de

Desenvolvimento Cientifico e Tecnológico; USP = Universidade de São Paulo.

For more information, see Instructions for authors. 


\section{References}

1. Valente AA Jr, Miguel EC, Castro CC, Amaro E Jr, Duran FL, Buchpiguel CA, Chitnis X, McGuire PK, Busatto GF. Regional gray matter abnormalities in obsessive-compulsive disorder: a voxel-based morphometry study. Biol Psychiatry. 2005;58(6):479-87.

2. Chamberlain SR, Blackwell AD, Fineberg NA, Robbins TW, Sahakian BJ. The neuropsychology of obsessive compulsive disorder: the importance of failures in cognitive and behavioural inhibition as candidate endophenotypic markers. Neurosci Biobehav Rev. 2005;29(3):399-419.

3. Bressan RA, Shih MC, Hoexter MQ, Lacerda AL. Can molecular imaging techniques identify biomarkers for neuropsychiatric disorders? Rev Bras Psiquiatr. 2007;29(2):102-4.

4. Evans KC, Dougherty DD, Pollack MH, Rauch SL. Using neuroimaging to predict treatment response in mood and anxiety disorders. Ann Clin Psychiatry. 2006;18(1):33-42.

5. Pauls DL. The genetics of obsessive compulsive disorder: a review of the evidence. Am J Med Genet C Semin Med Genet. 2008; $148 \mathrm{C}(2): 133-9$

6. Perani D, Garibotto V, Gorini A, Moresco RM, Henin M, Panzacchi A, Matarrese M, Carpinelli A, Bellodi L, Fazio F. In vivo PET study of $5 \mathrm{HT}(2 \mathrm{~A})$ serotonin and $\mathrm{D}(2)$ dopamine dysfunction in drug-naive obsessive-compulsive disorder. Neuroimage. 2008;42(1):306-14.

7. Simpson HB, Lombardo I, Slifstein M, Huang HY, Hwang DR, AbiDargham A, Liebowitz MR, Laruelle M. Serotonin transporters in obsessive compulsive disorder: a positron emission tomography study with [(11)C]McN 5652. Biol Psychiatry. 2003;54(12):1414-21.

8. Schneier FR, Martinez D, Abi-Dargham A, Zea-Ponce Y, Simpson $H B$, Liebowitz MR, Laruelle M. Striatal dopamine $D(2)$ receptor availability in OCD with and without comorbid social anxiety disorder: preliminary findings. Depress Anxiety. 2008;25(1):1-7.

9. Miguel EC, Leckman JF, Rauch S, do Rosario-Campos MC, Hounie AG, Mercadante MT, Chacon P, Pauls DL. Obsessive-compulsive disorder phenotypes: implications for genetic studies. Mol Psychiatry. 2005; 10(3):258-75.

10. Busatto GF, Buchpiguel CA, Zamignani DR, Garrido GE, Glabus MF, Rosario Campos MC, Castro CC, Maia A, Rocha ET, McGuire PK, Miguel EC. Regional cerebral blood flow abnormalities in early-onset obsessive-compulsive disorder: an exploratory SPECT study. J Am Acad Child Adolesc Psychiatry. 2001;40(3):347-54.

11. Saxena S, Gorbis E, O'Neill J, Baker SK, Mandelkern MA, Maidment KM, Chang S, Salamon N, Brody AL, Schwartz JM, London ED. Rapid effects of brief intensive cognitive-behavioral therapy on brain glucose metabolism in obsessive-compulsive disorder. $\mathrm{Mol}$ Psychiatry. 2009;14(2):197-205.

12. Foa EB, Liebowitz MR, Kozak MJ, Davies S, Campeas R, Franklin ME, Huppert JD, Kjernisted K, Rowan V, Schmidt AB, Simpson HB, Tu X. Randomized, placebo-controlled trial of exposure and ritual prevention, clomipramine, and their combination in the treatment of obsessivecompulsive disorder. Am J Psychiatry. 2005;162(1):151-61.

13. Linden DE. How psychotherapy changes the brain--the contribution of functional neuroimaging. Mol Psychiatry. 2006;11(6):528-38.

14. Miguel EC, Ferrão YA, Rosário $M C$, de Mathis MA, Torres AR, Fontenelle LF, Hounie AG, Shavitt RG, Cordioli AV, Gonzalez CH, Petribú K, Diniz JB, Malavazzi DM, Torresan RC, Raffin AL, Meyer E, Braga DT, Borcato S, Valério C, Gropo LN, Prado Hda S, Perin EA, Santos SI, Copque H, Borges MC, Lopes AP, Silva ED; Brazilian Research Consortium on Obsessive-Compulsive Spectrum Disorders. The Brazilian Research Consortium on Obsessive-Compulsive Spectrum Disorders: recruitment, assessment instruments, methods for the development of multicenter collaborative studies and preliminary results. Rev Bras Psiquiatr. 2008;30(3):185-96.

15. Diniz J, Shavitt R, Pereira C, Hounie A, Pimentel I, Koran L, Dainesi S, Miguel E. Quetiapine versus clomipramine in the augmentation of selective serotonin reuptake inhibitors for the treatment of obsessive-compulsive disorder: a randomized, open-label trial. J Psychopharmacol. 2009 (in press).

16. Belotto-Silva C, Diniz JB, Marino DM, Valério C, Fossaluza V, Borcato S, Seixas A, Miguel E, Shavitt RG. Group cognitive-behavioral therapy versus selective serotonin reuptake inhibitors for obsessivecompulsive disorder: a practical clinical trial. Psychother Psychosom. Submitted 2009.
17. Fossaluza V, Diniz J, Pereira B, Miguel E, Pereira, C. Sequential allocation and balancing prognostic factors. Clinics. 2009;64(6):511-8.

18. Miller SA, Dykes DD, Polesky HF. A simple salting out procedure for extracting DNA from human nucleated cells. Nucleic Acids Res. 1988;16(3): 1215 .

19. Wechsler D. Wechsler abbreviated scale of IQ. San Antonio (TX): Psychological Corporation, Harcourt Brace \& Company; 1999.

20. Reitan RM, Wolfson D. The Halstead-Reitan neuropsychological test battery: Theory and clinical interpretation. Tucson (AZ): Neuropsychology Press; 1985.

21. Wechsler D. Wechsler adult intelligence scale. 3rd ed. San Antonio (TX): Psychological Corporation, Harcourt Brace \& Company; 1997.

22. Jurado MA, Mataro $M$, Verger $K$, Bartumeus $F$, Junque $C$. Phonemic and semantic fluencies in traumatic brain injury patients with focal frontal lesions. Brain Inj. 2000;14(9):789-95.

23. Rey A. Figuras Complexas de Rey: Teste de cópia e de recuperação de memória de figuras geométricas complexas. Tradução de Terezinha Rey, Lucia Cristina Fleury Franco e adaptação brasileira de Margareth da Silva Oliveira. São Paulo: Casa do Psicólogo; 1998-1999.

24. Benedict RH. Brief visual memory test - revised: Professional manual. Odessa (FL): Psychological Assessment Resources; 1997. 54B, p.94-9.

25. Delis DC, Kramer JH, Kaplan E, Ober BA. California verbal learning test. 2nd ed. San Antonio (TX): The Psychological Corporation; 2000.

26 Trites RL. Neuropsychological test manual. Ottawa, Ontario, Canada: Royal Ottawa Hospital; 1977.

27. Eimer M. Effects of attention and stimulus probability on ERPs in a Go/Nogo task. Biol Psychol. 1993;35(2):123-38.

28. Regard M. Cognitive rigidity and flexibility: a neuropsychological study [dissertation]. Victoria (BC): University of Victoria; 1981.

29. Heaton RK. Wisconsin card sorting test manual. Odessa (FL): Psychological assessment resources; 1981.

30. Freedman, M. Object alternation and orbitofrontal system dysfunction in Alzheimer's and Parkinson's disease. Brain Cogn. 1990;14(2):134-43.

31. Burgess PW, Shallice T. The Hayling and Brixton tests. Bury St Edmunds: Thames Valley Test Company; 1997.

32. Bechara A, Tranel D, Damasio H. Characterization of the decisionmaking deficit of patients with ventromedial prefrontal cortex lesions. Brain. 2000;123(Pt 11):2189-202.

33. Fletcher PC, Happé F, Frith U, Baker SC, Dolan RJ, Frackowiak $\mathrm{RS}$, Frith $\mathrm{CD}$. Other minds in the brain: a functional imaging study of "theory of mind" in story comprehension. Cognition. 1995;57(2):109-28.

34. Del Prette ZAP, Del Prette A. Inventário de habilidades sociais: Manual de aplicação, apuração e interpretação. São Paulo: Casa do Psicólogo; 2001.

35. Choi SR, Kung MP, Plössl K, Meegalla S, Kung HF. An improved kit formulation of a dopamine transporter imaging agent: [Tc-99m] TRODAT-1. Nucl Med Biol. 1999;26(4):461-6.

36. Shih MC, Amaro E Jr, Ferraz HB, Hoexter MQ, Goulart FO, Wagner J, Lin LF, Fu YK, Mari JJ, de Lacerda AL, Tufik S, Bressan RA. Neuroimaging of the dopamine transporter in Parkinsons disease: first study using [99mTc]-TRODAT-1 and SPECT in Brazil. Arq Neuropsiquiatr. 2006;64(3A):628-34.

37. Torres AR, Prince MJ, Bebbington PE, Bhugra D, Brugha TS, Farrell $M$, Jenkins R, Lewis G, Meltzer H, Singleton N. Obsessive-compulsive disorder: prevalence, comorbidity, impact and help-seeking in the British National Psychiatric Morbidity Survey of 2000. Am J Psych. 2006;163(11):1978-85.

38. Fontenelle LF, Mendlowicz MV, Marques C, Versiani M. Trans-cultural aspects of obsessive-compulsive disorder: a description of a Brazilian sample and a systematic review of international clinical studies. $J$ Psychiatr Res. 2004;38(4):403-11.

39. Tunis SR, Stryer DB, Clancy CM. Practical clinical trials: increasing the value of clinical research for decision making in clinical and health policy. JAMA. 2003;290(12):1624-32. 